\title{
Episema glaucina (ESPER, [1789]) in Poland (Lepidoptera: Noctuidae)
}

\author{
JANUSZ NOWACKI $^{1 *}$, ŁUKASZ DAWIDOWICZ ${ }^{2}$, DAMIAN SUDOŁ ${ }^{3}$, \\ ROMAN WĄSALA ${ }^{1}$ \\ ${ }^{1}$ Department of Entomology and Environmental Protection, Poznań University \\ of Life Sciences, ul. Dąbrowskiego 159, 60-594 Poznań, Poland \\ ${ }^{2}$ ul. Droga Męczenników Majdanka 53/39, 20-325 Lublin, Poland \\ ${ }^{3}$ ul. Bolesława Prusa 26A, 36-060 Głogów Małopolski, Poland
}

\begin{abstract}
Episema glaucina (Lepidoptera: Noctuidae) has been recorded for the first time in Poland following the faunistic revision of material collected by A.S. KOSTROWICKI in the Nida Valley in the early 1950s, and on the basis of specimens trapped during fieldwork in the same region of the Małopolska Upland in southern Poland.
\end{abstract}

KEY WORDS: Lepidoptera, Noctuidae, Episema glaucina, Episema tersa, faunistic revision, new record, Poland.

\section{INTRODUCTION}

The Western Palearctic genus Episema OCHSENHEIMER, 1816, contains 16 species. It has a Ponto-Mediterranean-Turkestanian distribution: from the Atlantic in the west, across southern and central Europe and north Africa, to Asia Minor and the countries of the Levant, the southern Urals, the Caucasus, Turkmenistan, Kazakhstan and Chinese Turkestan (FibigER et al. 2006, PoOLE 1989, RONKAY et al. 2001). Seven of these species occur in Europe, and two - Episema glaucina (ESPER, [1789]) and E. tersa ([DENIS \& SCHIFFERMÜLLER], 1775) - are present in central Europe (NOWACKI 1998). In eastcentral Europe, the distribution of these two species is sympatric. However, only $E$. glaucina occurs to the west of central Europe all the way to the Atlantic Ocean: in Europe

\footnotetext{
* Corresponding author: janusz.nowacki@up.poznan.pl
} 
this species has been recorded from Portugal, Spain, France and southern Belgium, across southern and central Germany, Italy, the Czech Republic, Hungary, Slovakia and southern Ukraine and the Balkan Peninsula, to the southern Urals and the Caucasus (RONKAY et al. 2001). E. tersa, in turn, has a more easterly distribution than the previous species: it occurs to the east as far as Kazakhstan and the western part of the Chinese Tien Shan mountains, while it reaches its western range limit in central Europe, in eastern Austria, the eastern Czech Republic, Hungary and the countries of the Balkan Peninsula (NowACKI \& FibIGER 1996, RÁKOSY 1996, RONKAY et al. 2001). Of the two species, only E. tersa has so far been recorded in Poland: the record comes from the mid-20 th century, and from just a single locality - the xerothermic hills in the Nida Valley near Pińczów (KosTROWICKI 1953). It is worth stressing that not only do the two species occur sympatrically in central Europe; they are also very similar in external appearance (Fig. 1), which itself is subject to a certain intraspecific individual variability. Moreover, both species inhabit similar

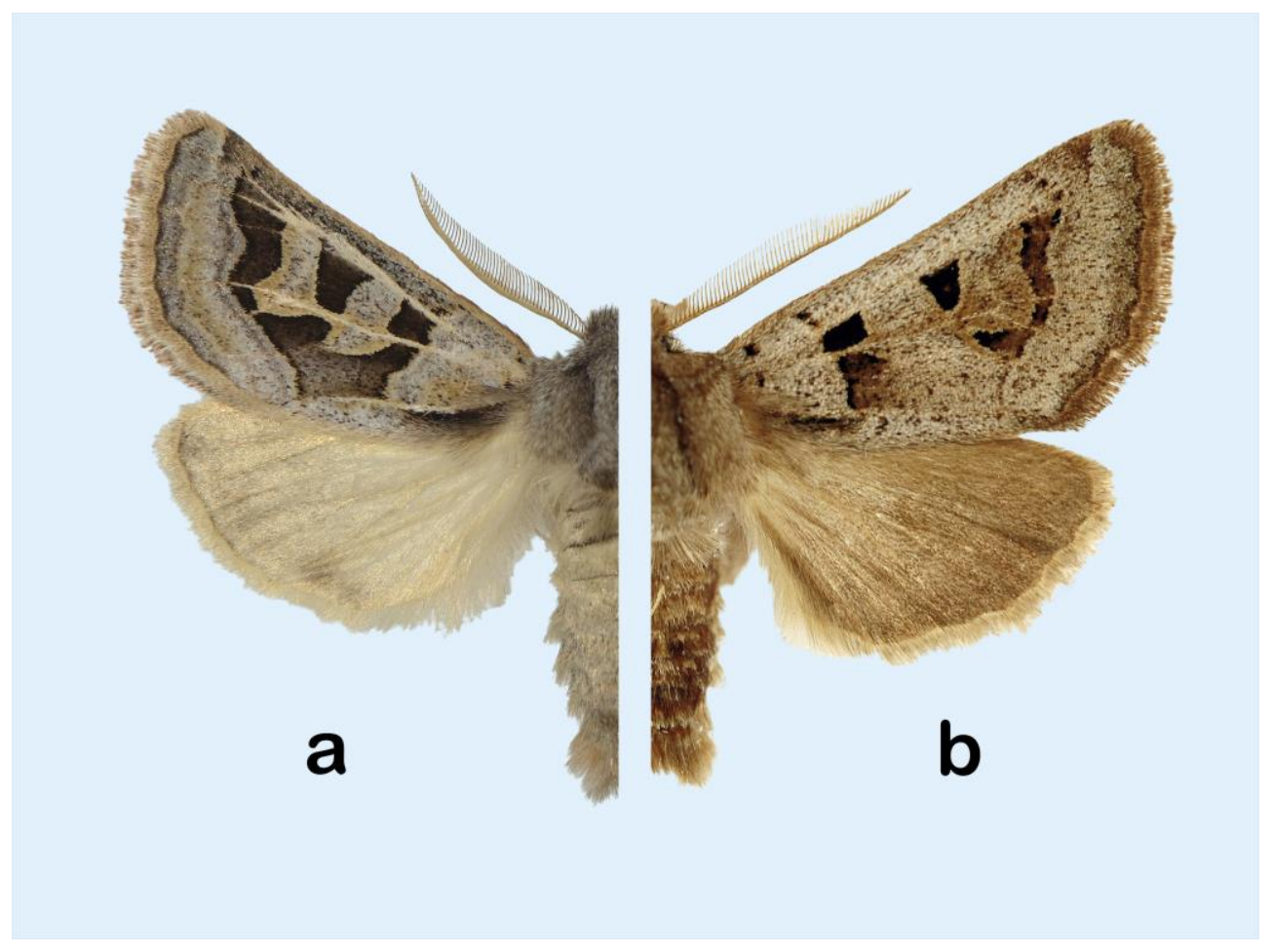

Fig. 1. Comparison of the external appearance of imagines: a - Episema glaucina (Poland, Nida Valley ad Pińczów) and b - Episema tersa (Hungary, from the Catalogue of the Heterocera Press). 
environments, i.e. the xerothermic swards and forest steppe ecosystems found on hillsides and the slopes of low mountains, especially with a calcareous substrate. The caterpillars of both species feed on Anthericum L., Muscari MiLl. and Ornithogalum L. (RONKAY et al. 2001). Episema glaucina is much more widely distributed in central Europe than E. tersa, having been recorded far more often and at a greater number of localities, also near its northern range boundary, in countries bordering on Poland, i.e. in Germany (GAEDIKE et al. 2017, LÖBEL \& KAITER 1989), the Czech Republic (LAŠTU゚VKA \& LIŠKA 2011), Slovakia (REIPRICH \& OKALI 1989), south-east Ukraine (KLYUCHKO 2006, NOWACKI et al. 2018, ROMANISZYN \& SCHILLE 1929, ŚWIĄTKIEWICZ 1930), as well as Hungary (VARGA et al. 2005) and Romania (RÁKOSY 1996). It is in the light of these facts that we formulated our research hypothesis, namely, that there is a greater probability of finding E. glaucina in Poland than its congener. In order to test this hypothesis, we had to reassess the identifications of the voucher specimens in KOSTROWICKI's collection and to try to find the species in the field.

\section{MATERIALS AND METHODS}

The research material - imagines of Episema spp. occurring in Poland - was accumulated in two ways. To begin with, a revision was undertaken of the collection of Professor A.S. KostrowiCKI, which is housed at the Museum and Institute of Zoology, Polish Academy of Sciences (PAN), Warsaw. It contains, inter alia, voucher specimens from the professor's studies of the Lepidoptera of the Nida Valley (Świętokrzyskie province) in the early 1950s, among them, 3 exx. of Episema spp. The identity of these specimens was to be reassessed. The second part of this work involved a field search for Episema spp. in Poland. This was narrowed down to the xerothermic hills above the valley of the River Nida near Pińczów in the Małopolska Upland. Many of these hills and slopes have a substrate of gypsum and most have a southerly to south-westerly exposure. These slopes support xerothermic sward ecosystems where Anthericum ramosum L., one of the host plants of the moths under investigation, grows in abundance (Fig. 2). Imagines were attracted at night in many different localities to a white screen illuminated by a 250 W mercury vapour lamp powered by a portable generator. Moths were also caught with a series of portable actinic traps equipped with blacklights (TL 6W/08 - Philips), which were deployed each night in diverse ecosystems. 

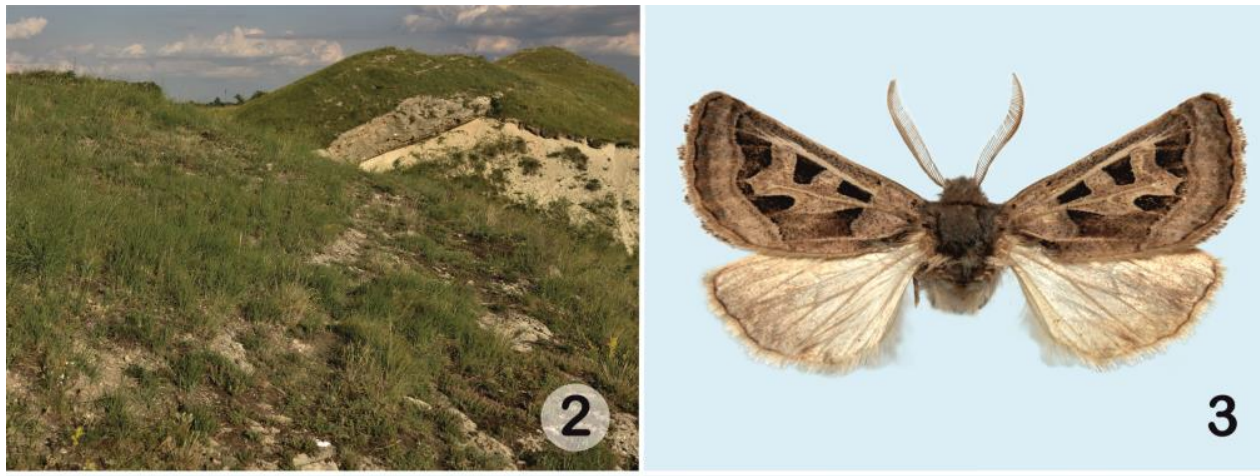

3
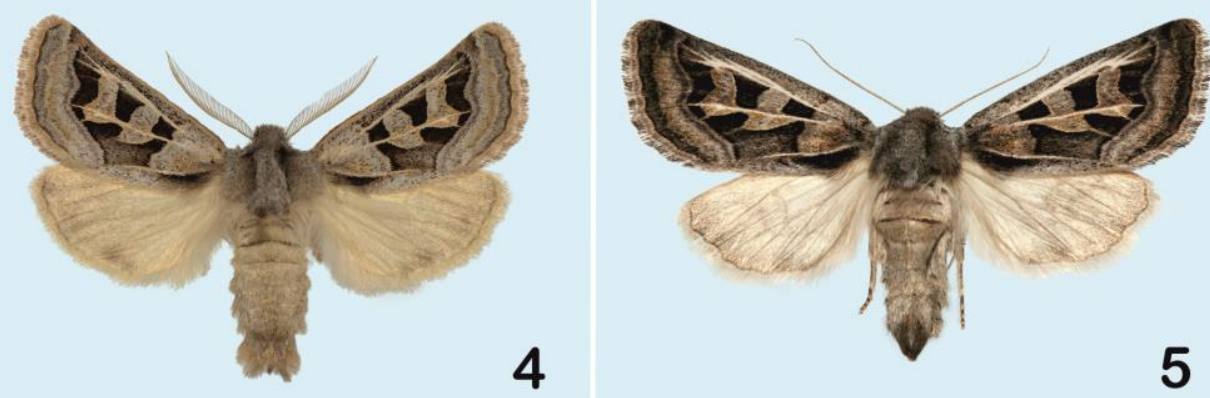

Fig. 2-5. 2 - Part of the xerothermic sward on the slope of a gypsum hill in the vicinity of Gacki ad Pińczów, the developmental habitat of Episema glaucina. 3-5 - Imagines of E. glaucina from Poland: 3 - Krzyżanowice Nature reserve ad Pińczów, 31 VIII 1952, leg. A. Kostrowicki; 4 - Gacki ad Pińczów, 8 IX 2016, leg. D. SUdOŁ and Ł. DawidowicZ; 5 - Winiary ad Pińczów, 17 IX 2018, leg. J. NOWACKI and R. WĄSALA.

\section{RESULTS}

The fieldwork carried out on the xerothermic hills overlooking the Nida Valley near Pińczów in the Małopolska Upland yielded only one species from the genus Episema, namely E. glaucina:

- the Nida Basin (Niecka Nidziańska), xerothermic slope ad Gacki UTM: DA78, 8 IX 2016, 14 exx., leg. D. SUdOŁ and Ł. DAwIDOWICZ (Fig. 4); xerothermic slope ad Winiary UTM: DA78, 17 IX 2018, 2 exx., leg. J. NOWACKI and R WĄSALA. (Fig. 5). 
These records supported our contention that the historical material in KosTROWICKI's collection, originally labelled as E. tersa, in fact contained 3 exx. E. glaucina:

- Nida Basin (Niecka Nidziańska): Grabowiec Nature Reserve UTM: DA79, 1 VII 1950,

1 ex., leg. A. Kostrowicki; Krzyżanowice Nature Reserve UTM: DA68, 31 VIII 1952,

2 exx., leg. A. Kostrowicki (Fig. 3).

\section{DISCUSSION}

The results confirmed our research hypothesis that E. glaucina occurs in Poland rather than $E$. tersa. We were unable to confirm the presence of $E$. tersa, earlier records of which had been based on specimens obtained from the Grabowiec Nature Reserve ad Gacki by KOSTROWICKI (1 VII 1950) and ŚWIDERSKI (8 IX 1951) (KOSTROWICKI 1953). We should emphasise, however, that in his paper on the Lepidoptera of the Nida Valley, KosTrowICKI mentioned the species Derthisa trimacula ([DENIS \& SCHIFFERMÜLLER], 1775), this appellation has long been regarded as a synonym of $E$. tersa. He may, of course, have been influenced by the finding of $D$. trimacula by RoMANISZYN \& SCHILLE (1929) in Poland (pre-war borders) who stated that E. glaucina was a synonym of this species. Those authors reported records of this species from Janów near Lwów (now Lviv) (after STÖCKL) and from Tarnów (after GARBOwSKI). That is why the name E. tersa was used in later literature on the occurrence of Lepidoptera in Poland (BUSZKO \& NOWACKI 2017). Some doubt surrounds the fact that, having made the genitalia preparation from the specimen from the Grabowiec Nature Reserve, KosTROWICKI labelled it "Derthisa trimacula dentimacula HBN.", thus using the synonyms of two different species to identify this specimen (Noctua dentimacula HÜBNER, 1790 is one of the synonyms of E. glaucina). However, he did not give the correct name of the species either in his report (KOSTROWICKI 1953) or in his later key to the Cuculliinae (KostrowICKI 1956). It is highly likely, therefore, that the species was misidentified. That this must have been the case is shown by our revision of the historical material, namely KosTROWICKI's voucher specimens at the Museum and Institute of Zoology PAN, Warsaw, which turn out to be solely E. glaucina. Another doubtful aspect is the date -1 July - on which KostrowicKI caught one of those specimens. Such a date on the label seems to be quite wrong, as the flight period of E. glaucina in central Europe lasts from late August to early October (NOWACKI 1998, NOWACKI et al. 2018, RONKAY et al. 2001). During our fieldwork, we caught E. glaucina between 8 and 17 September.

The confirmation of the occurrence of E. glaucina in Poland and the simultaneous absence of $E$. tersa reorganises our knowledge to date regarding the northern range limits of these two species in central Europe. The distribution of E. tersa in central Europe appears not to extend north of the Sudeten and Carpathian mountain ranges, whereas E. glaucina is 
found much farther north, in southern and central Germany, southern Poland and southern Ukraine, also to the north of the Carpathians (Fig. 6) (GAEDIKE et al. 2017, LAŠTƯVKA \& LIŠKA 2011, LÖBEL \& KAITER 1989, NOWACKI et al. 2018, REIPRICH \& OKALI 1989, ROMANISZYN \& SCHILLE 1929, ŚWIĄTKIEWICZ 1930).

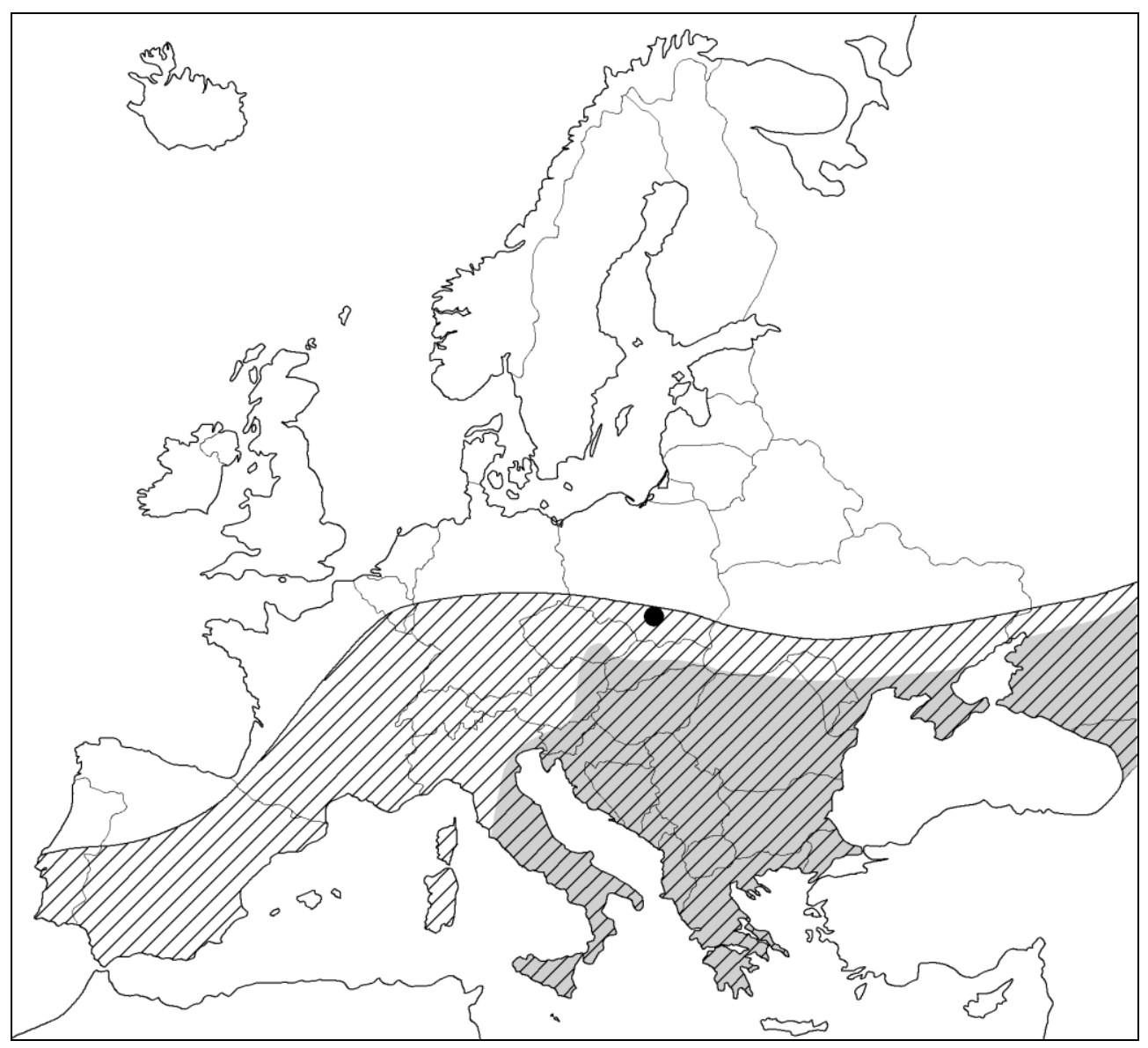

Fig. 6. A general outline of the distributions of Episema glaucina (hatched area) and E. tersa (grey) in Europe. The black dot indicates the new locality of E. glaucina in Poland.

\section{ACKNOWLEDGEMENTS}

The authors would like to thank Gábor RONKAY (Heterocera Press Ltd.) and László RONKAY (Department of Zoology, Hungarian Natural History Museum) for lending us the 
photographs of Episema tersa for this paper. We also thank the Staff of the Museum and Institute of Zoology PAN, Warsaw, for making the Lepidoptera collection at Łomna available to us for investigation.

\section{REFERENCES}

Buszko J., Nowacki J. 2017. The Lepidoptera of Poland. A Distributional Checklist. Polish Entomological Monographs, 13. Polish Entomological Society, Poznań.

Fibiger M., Kravchenko V.D., Mooser J., Li C., Muller G.C. 2006. The Species of the Genus Episema OCHSENHEIMER, 1816 from Israel: Distribution, Phenology and Ecology; with Taxonomical Notes and the Description of Two New Species (Lepidoptera: Noctuidae). SHILAP Revista de Lepidopterología, 34 (136): 383-394.

Gaedike R., Nuss M., Steiner A., Trusch R. 2017. Entomofauna Germanica Band 3. Verzeichnis der Schmetterlinge Deutschlands (Lepidoptera). Entomologische Nachrichten und Berichte, 21: $1-362$.

KLYUChKo Z. 2006. Noctuid Moths of Ukraine. Izdatel'stvo Raevskogo, Kiev. (in Ukrainian)

KostrowiCKI A.S. 1953. Studies on the fauna of butterflies of the xerothermic hills over the lower Nida. Fragmenta Faunistica Musei Zoologici Polonici, 6 (16): 263-447. (in Polish)

Kostrowicki A.S. 1956. Keys for the Identification of Polish Insects. Part XXVII, Butterflies Lepidoptera, issue 53a, owlet moths - Noctuidae. PWN, Warszawa. (in Polish)

LAŠTŮVKA Z., LiŠKA J. 2011. Annotated checklist of moths and butterflies of the Czech Republic. Biocont Laboratory spol. S r.o., Brno.

LÖBEL H., KAITER G. 1989. Zum Vorkommen und Lebensweise von Episema glaucina (EsPER, 1789) in Thüringen (Lepidoptera: Noctuidae). Nota Lepidopterologica, 12 (1): 19-20.

NowACKI J., 1998. The Noctuids (Lepidoptera, Noctuidae) of Central Europe. František Slamka, Bratislava.

Nowacki J., Fibiger M. 1996. Noctuidae. [in:] O. KARShOlt, J. RAZOwSKi (eds.). The Lepidoptera of Europe. Apollo Books, Stenstrup, 249-293.

NOWACKI J., WĄSALA R., ZYDLIK P. 2018. Noctuid moths of xerothermic habitats in the Chorna Hora Botanical Reserve in Transcarpathia (Ukraine) (Lepidoptera: Nolidae, Erebidae, Noctuidae). SHILAP Revista de Lepidopterología, 46 (184): 593-614.

Poole R.W. 1989. Lepidopterorum Catalogus (New Series) Fasc 118 Part 1. Noctuidae Part 1. CRC Press, Leiden - New York - København - Köln.

RÁKosy L. 1996. Die Noctuiden Rumäniens. Land Oberösterreich, Oberösterreichisches Landesmuseum, Linz.

REIPRICH A., OKALI I. 1989. Additions to the preliminary work of Lepidoptera of Slovakia, volume 2. VEDA vydavatelstvo Slovenskej Akademie Vied, Biologicke Prace, Bratislava. (in Slovak)

Romaniszyn J., Schille F. 1929. Butterfly fauna of Poland, Volume 1. Prace monograficzne Komisji Fizjograficznej, 4: 1-552. (in Polish) 
Ronkay L., Yela J.L., Hreblay M. 2001. Noctuidae Europae, vol. 5, Hadeninae II. Entomological Press, Sorø.

ŚwiątKiewicz M. 1930. Seltenere und für neue Polen Lepidopteren aus Podolien. II Beitrag. Polskie Pismo Entomologiczne, 9 (1-2): 87-92. (in Polish)

Varga Z., Ronkay L., Balint Z., Gyula L. M., Peregovits L. 2005. Checklist of the fauna of Hungary, Vol. 3, Macrolepidoptera. Hungarian Natural History Museum, Budapest.

Received: 1 January 2019

Accepted: 26 February 2019 